
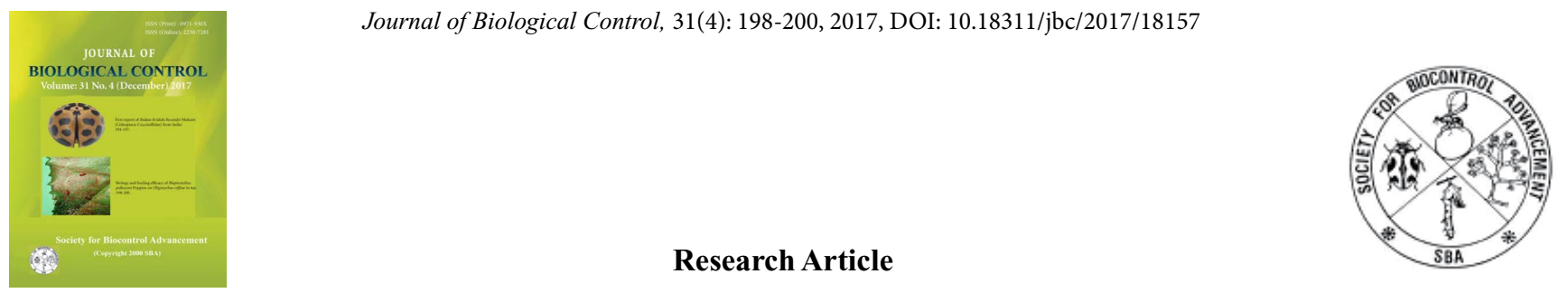

\title{
Biology and feeding efficacy of the anthocorid, Blaptostethus pallescens Poppius on Oligonychus coffeae in tea
}

\author{
KODAKKADAN SRIKUMAR ${ }^{*}$, S. SMITHA, B. SURESH KUMAR and B. RADHAKRISHNAN \\ Department of Entomology, UPASI Tea Research Foundation, Valparai, Coimbatore - 642 127, Tamil Nadu, India \\ ${ }^{*}$ Corresponding author E-mail: sreeku08@gmail.com
}

\begin{abstract}
The anthocorid predator, Blaptostethus pallescens Poppius was studied for the first time on red spider mite (RSM), Oligonychus coffeae Nieter. Laboratory studies indicated that $B$. pallescens can be successfully reared on RSM. Incubation period was 4.4 \pm 0.34 days. The total developmental period of five nymphal instars to adults was $17.1 \pm 0.34$ days. Blaptostethus pallescens nymphs consumed RSM in the range of $3.83 \pm 0.18$ to $17.37 \pm 0.95 /$ day. Female $B$. Pallescens consumed more mites than male. The study clearly showed $B$. pallescens is a promising candidate in tea plantations for the control of red spider mite.
\end{abstract}

KEY WORDS: Blaptostethus pallescens, biology, predator, red spider mite, tea

(Article chronicle: Received: 25-10-2017; Revised: 26-11-2017; Accepted: 30-12-2017)

\section{INTRODUCTION}

Oligonychus coffeae Nieter (Acari: Tetranychidae) the red spider mite (RSM), is a major pest of tea. Nymphs and adults of RSM lacerate cells, producing minute characteristic reddish brown marks on the upper surface of the mature leaves, which turn red in severe case of infestation, resulting in crop loss. There are several control measures adapted to check the RSM population. The control measures include spraying of acaricides and bioproducts. These measures may introduce problems like insecticide resistance, residue, health hazards and environmental pollution. Hence non-chemical and eco-friendly methods of pest control are in trend.

Anthocorids are known to be potential predators on several pests on different crop ecosystem (Muraleedharan and Ananthakrishnan, 1978; Ballal et.al., 2009; Gupta et al.,2011). Anthocorids such as Anthocoris pilosus (Jakovlev), Cardiastethus poweri White, Cardiastethus consors White, Orius albidipennis Reuter, Orius vicinus (Ribault), Orius majusculus (Reuter), Orius minutus (Linnaeus), Orius niger (Wolff), Orius tristicolor (White) and Orius thripoborus (Hesse) were observed to be potential predators of mites in different countries (CABI, 2006). Blaptostethus pallescens Poppius (Hemiptera: Anthocoridae) has been found to be potential predator of pests of maize and mites of grain warehouses in Egypt (Tawfik et al., 1974; Tawfik and El-Hussain, 1971). Blaptostethus kumbi Rajasekara collected from sugarcane fields in Mysore (Rajasekhara, 1973); $B$. pallescens from Tamil Nadu and Bombay (Muraleedharan, 1977) and Bangalore (Jalali and Singh, 2002). B. pallescens has also been recorded from Madagascar (Muraleedharan, 1977) and from grain warehouses in Egypt, where mites were common (Tawfik and El-Husseini, 1971). Laboratory studies indicated that B. pallescens could feed on 190 and 116 two spotted spider mites, Tetranychus urticae Koch (Acari: Tetraychidae) nymphs during its nymphal and adult stages (Ballal et al., 2009).

Blaptostethus pallescens can be intensively cultured, without encountering problems of cannibalism and excessive handling; thus making it amenable to commercial production (Ballal., et al. 2003). Hence attempts were made to culture this predator in the laboratory and to study its biology and feeding potential. Through the present study, an attempt was made to evaluate the efficacy of $B$. Pallescens as a predator of Oligonychus coffeae in the laboratory.

\section{MATERIALS AND METHODS}

Red spider mites were collected from the tea fields of 
UPASI Experimental Farm, Anamallais (Coimbatore District, Tamil Nadu, India) $\left(10^{\circ} 22^{\prime} \mathrm{N}\right.$ latitude, $76^{\circ} 58^{\prime} \mathrm{E}$ longitude and $1065 \mathrm{~m}$ a.s.l) and reared in laboratory. RSM adults were transferred onto fresh tealeaves placed over moist cotton wool kept in plastic trays $(42 \times 30 \times 6.5 \mathrm{~cm})$ (Vasanthakumar and Babu, 2013).

Nymphs and adults of $B$. Pallescens were obtained from mass production laboratory at the National Bureau of Agriculturally Important Insect Resources (NBAIR, Bangalore, India). Pearl pet plastic containers of $500 \mathrm{ml}$ capacity were used to culture the anthocorids. The containers were provided with tea shoots in a water fitted vial. RSM was placed on the leaves using a soft brush. Pollen was sprinkled on cotton. A swab of cotton soaked in water was stuck to the wall of the container. One container could hold 10 adults and replicated 20 times. The eggs were laid in tea shoots, inserted into the tissue with only operculum of the eggs visible. After 24hrs, the shoots with eggs were removed and placed in small, round, ventilated plastic containers (dia 6.5 $\mathrm{cm}$ and $\mathrm{ht} 2.5 \mathrm{~cm}$ ) when the nymphs hatched, they were shifted to pearl pet jars provided with RSM on tea leaves. Feeding was provided on alternate days till adults emerged. The freshly emerged adults were shifted to pearl pet jars with tea shoots and seeds for oviposition.

In order to study the feeding potential of nymphs five sets of ventilated container, described above, were arranged with newly hatched nymph in each container. 10 number of red spider mite adults were placed on a piece of tea leaf and kept inside the container. After every $24 \mathrm{~h}$ period, the number of live RSM was recorded and another set of RSM was provided. The RSM number was increased for different instars i.e., 10, 15, 20, 25 and 30 for I, II,III, IV and V instars. The experiment was replicated five times.

The feeding potential of adult male and female was also studied. The method was same as that followed for nymphs. The adults were provided with 50 numbers of RSM adults per day till mortality.

\section{RESULT AND DISCUSSION}

Blaptostethus pallescens was reared successfully on RSM. The biological parameters are presented in Table1.
The newly hatched nymphs developed normally with five nymphal instars and became adults in $17.1 \pm 0.34$ days. Fifth instar showed longest development period $(7.5 \pm$ 0.16).Total developmental period varied from 20-24 days i.e., an average of $21.5 \pm 0.5$ days.

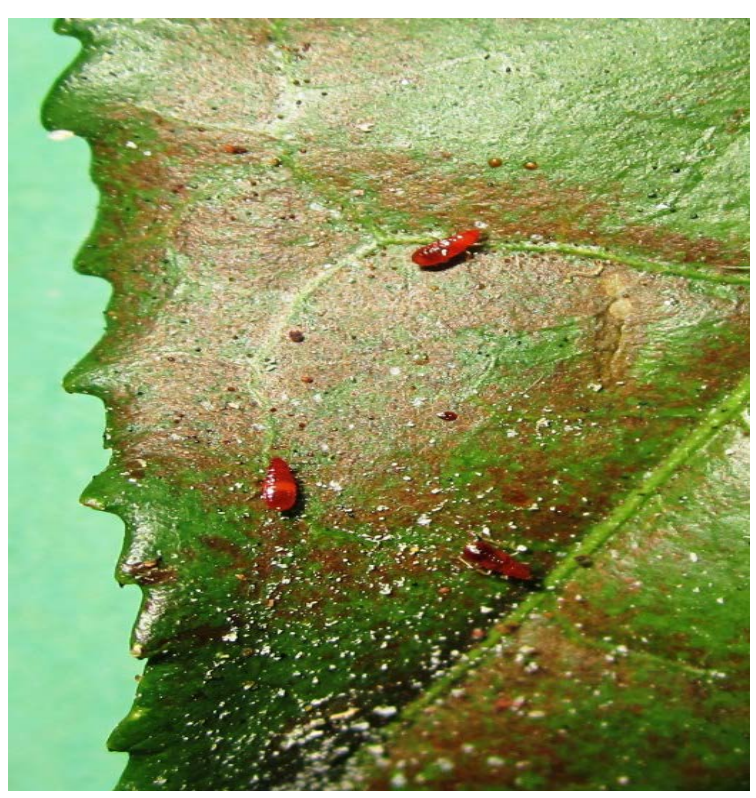

Fig. 1. Blaptostethus pallescens feeding on Oligonychus coffeae.

Mean longevity of adult male and female was 39.6 \pm 4.82 and $43.7 \pm 4.19$ days respectively (Table 2 ). Ballal et al., 2003 reported that when B. pallescens were reared on UV- irradiated eggs of Corcyra cephalonica, adult male and female longevity was 42.4 and 58.2 days respectively. Similar investigation was made by Tawfik and El Hussieni (1971) was male and female longevity was 17.7 and 24.4 days respectively when fed with lepidopteran larvae. The female: male ratio was 1.2:1. This was similar to the studies conducted by Ballal et al. (2003) and Tawfik and El Hussieni (1971).

Number of RSM consumed per B. Pallescens ranged between $3.83 \pm 0.18$ to $17.37 \pm 0.95$ during their nymphal period. Ballal et al. (2003) observed that feeding potential of B. pallescens nymph on Corcyra eggs ranged between 83 to 130. It was reported that $B$. Pallescens can feed upto 40 twospotted spider mites (Tetranychus urticae) per day (Ballal et al., 2009). The result indicated that the feeding potential increased with the age. The adult male consumed an average

Table 1. Incubation and stadial periods of Blaptostethus pallescens

\begin{tabular}{|l|l|l|l|l|l|l|l|l|}
\hline Species & $\begin{array}{l}\text { Incubation } \\
\text { Period (d) }\end{array}$ & \multicolumn{2}{|l|}{ Stadial period (d) (Mean \pm SE) } & \multicolumn{4}{|l|}{ (Mean \pm SE) } \\
\cline { 3 - 9 } & I & II & III & IV & V & $\begin{array}{l}\text { Total nym- } \\
\text { phal period } \\
\text { (d) }\end{array}$ & $\begin{array}{l}\text { Total } \\
\text { developmental } \\
\text { period (d) }\end{array}$ \\
\hline B. pallescens & $4.4 \pm 0.34$ & $3.2 \pm 0.13$ & $1.8 \pm 0.13$ & $2.2 \pm 0.13$ & $2.4 \pm 0.16$ & $7.5 \pm 0.16$ & $17.1 \pm 0.35$ & $21.5 \pm 0.5$ \\
\hline
\end{tabular}


of $28.01 \pm 1.33$ adult RSM per day while adult female fed more than the adult male i.e., $33.57 \pm 0.72$ (Table 3). Blaptostethus pallescens adult female had higher feeding potential than male when fed with eggs of Corcyra cephalonica (Ballal et. al., 2003). In a study conducted by Bukero etal., 2014 on feeding performance of Menochilus sexmaculatus (Fabricuis) on Aphis gossypii (Glov.), Bemisia tabaci (Ginn.) and Amrasca biguttula biguttula(Distant), the adult female devoured highest number of nymphs of $A$. gossypii followed by $B$. tabaci and $A$. biguttula during its life span as compare to male.

Table 2. Longevity and fecundity of Blaptostethus pallescens

\begin{tabular}{|l|l|l|l|}
\hline \multirow{3}{*}{ Species } & \multicolumn{2}{|l|}{$\begin{array}{l}\text { Longevity (d) } \\
(\text { Mean } \pm \text { SE) }\end{array}$} & $\begin{array}{l}\text { Progeny produc- } \\
\text { tion } \\
\text { (nymphs/fe- } \\
\text { male) }\end{array}$ \\
\cline { 2 - 4 } & Male & Female & $136 \pm 22.6$ \\
\hline B. pallescens & $39.6 \pm 4.82$ & $43.7 \pm 4.19$ & \\
\hline
\end{tabular}

Table 3. Average number of RSM consumed/predator

\begin{tabular}{|l|l|}
\hline Predatory Stage & $\begin{array}{l}\text { RSM consumed/predator/day } \\
(\text { Mean } \pm \text { SE })\end{array}$ \\
\hline 1st instar & $3.83 \pm 0.18$ \\
\hline 2nd instar & $11.00 \pm 1.25$ \\
\hline 3rd instar & $11.58 \pm 0.83$ \\
\hline 4th instar & $15.08 \pm 1.27$ \\
\hline 5th instar & $17.37 \pm 0.95$ \\
\hline Adult male & $28.01 \pm 1.33$ \\
\hline Adult female & $33.57 \pm 0.72$ \\
\hline
\end{tabular}

\section{CONCLUSION}

The study showed that the anthocorid, Blaptostethus pallescens is an efficient predator of red spider mite. This predator can be utilized as an important biological control agent for the management of RSM in tea plantations. However, detailed field studies are required for measuring the performance of $B$. Pallescens against red spider mite and achieving this goal.

\section{ACKNOWLEDGEMENT}

The authors are grateful to Dr. Chandish R. Ballal, Director, National Bureau of Agricultural Important Insect Resources (ICAR, Bangalore) for providing the initial culture of $B$. pallescens.

\section{REFERENCES}

Ballal CR, Gupta T, Joshi S, Chandrashekhar K. 2009. Evaluation of an anthocorid predator Blaptostethus pallescens against two-spotted spider mite, Tetranychus urticae. In: Castane C. and Perdikis, D. (Eds). Integrated Control in Protected Crops. IOBC / WPRS Bulletin 49: 127-132.

Ballal CR, Singh SP, Poorani J, Gupta T. 2003. Biology and rearing requirement of an anthocorid predator Blaptostethus pallescens Poppius (Heteroptera: Anthcoridae). J Biol Control 17(1): 29-33.

Bukero A, Rustamani MA, Abro GH, Lodhi AM. 2014. Feeding Potential of Menochilus sexmaculatus (Fabricius) Against Sucking Insect Pests. J Basic Appl Sci. 10: 554-558. Crossref.

CABI. 2006. Crop Protection Compendium, Wallingford, UK, CAB International.

Gupta T, Ballal CR, Joshi S. 2011. Preferential feeding of an anthocorid predator Blaptostethus pallescens on different stages of cotton mealybug. J Environ Entomol. 33(4): 423-428.

Jalali SK, Singh SP. 2002. Seasonal activity of stem borers and their natural enemies on fodder maize. Entomon. 27(2): 137-146.

Muraleedharan N. 1977. Some genera of anthocorinae (Heteroptera: Anthocoridae) from South India. Entomon. 2: 231-235.

MuraleedharanN, Ananthakrishnan TN. 1978. Bioecology of four species of Anthocoridae predaciouson thrips. Rec Zool Surv India, Occasional paper II: 1-32.

Rajasekhara K. 1973. A new species of Blaptostethus (Hemiptera: Anthocoridae) from Mysore, India. Ann Entomol Soc Am. 66(1): 86-87. Crossref.

Tawfik MFS, El-Husseini MM. 1971. The life history of the anthocorid predator, Blaptostethus piceus Fieber var. pallescens Poppius (Hemiptera: Anthocoridae). Bull Soc Entomol Egypt 55: 239-252.

Tawfik MFS, Kira MT, Metwally SMI. 1974. On the abundance of major pests and their associated predators in corn plantations. Bull Soc Entomol Egypt 58: 168-177.

Vasanthakumar D, Babu A. 2013. Life table and efficacy of Mallada desjardinsi (Navas) (Chrysopidae: Neuroptera), an important predator of tea red spider mite, Oligonychus coffeae Nietner (Acari: Tetranychidae). Exp Appl Acarol. 61(1): 43. Crossref. PMid:23430022 